\title{
НАСИЛЬСТВЕННЫЕ ПРЕСТУПЛЕНИЯ ПРОТИВ ЖЕНЩИН: ИСТОРИЧЕСКИЙ ОБЗОР
}

\author{
НАРМИН Рабит Гызы Гошгарова - диссертант Центра судебной экспертизы \\ Министерства юстиции Азербайджанской Республики
}

DOI 10.32782/LAW.UA.2021.3.12

Преступнъие деяния, възваннъле насилием в семъе, происходят во всем мире, при этом ни различнъле уровни культурь народа и благосостояния государства, ни тем более материальное и социальное положение семьи, существенной роли не играют. Так, около $40 \%$ насильственных преступлений происходят в семьях. И в этом случае жертвами большей части этих преступлений становятся женщины. В уголовном законодательстве многих европейских стран и возникиих на постсоветском пространстве некоторьх государств преступления, связанные с насилием в семье, вълделенъ даже в самостоятельнъе главъ, а домашнее насилие криминализировано как самостоятельньии вид преступления.

В статье указывается, что, учитьлья исторические, социальнье, криминологические условия и моральнъге ченности, в каждъии исторический период в уголовном праве Азербайджана в достаточной мере охранялись основные неотьемлемъле права женщинь (жизнь, здоровъе, сексуальная неприкосновенность, личная свобода и достоинство). По мнению автора, в действующем уголовном законодательстве Азербайджанской Республики также должна бътть полностью сбормирована система преступлений бътоового насилия. Насильственнъле преступления, совершаемъле в целом на почве семейно-быттовых отношений, должны бътть определенъ как критерии дифбереницации уголовной ответственности за соответствующие преступления как в Особенной части Уголовно- го Кодекса (как отягчающие составъи соответствуюших видов преступлений насильственного характера против личности), так и в перечне обстоятельств, отягчаюших наказание в Общей части Уголовного Кодекса (статья 61) как критерии индивидуализачии наказания.

Ключевъие слова: уголовное право, преступление, наказание, уголовная ответственность, насильственнве преступления, преступления против жизни и здоровья, насильственнъие преступления против женщин.

Защита законных интересов личности, в особенности женщин, которые во многих случаях подвергаются бытовому насилию, и защита их прав и свобод от преступных посягательств - одна из важных внутренних функций государства в любом демократическом обществе. Учитывая важное значение вопросов защиты прав и свобод, Президент Азербайджанской Республики 27 ноября 2020 года подписал Указ об утверждении «Национального плана действий по борьбе с бытовым насилием в Азербайджанской Республике на 2020-2023 годы» в Азербайджанской Республике.

Во всем мире наблюдается рост числа насильственных преступлений, которые считаются последней формой социального и морального неблагополучия в обществе, а статистический анализ этих преступлений свидетельствует о том, что число посягательств на жизнь и здоровье женщин среди них довольно велик. 


\section{Кримінальне право, кримінальний процес та криміналістика}

Охрана жизни и здоровья человека является одним из основных целей демократического государства в современное время. Действующая правовая система в Азербайджанской Республике соответствующими правовыми средствами обеспечивает охрану жизни и здоровья каждого гражданина.

Следует отметить, что преступления против жизни и здоровья всегда являлись объектом уголовно-правовой борьбы во всех цивилизациях и на протяжении всей истории развития человечества.

Человеческая жизнь, дарованная природой, является одной из основных социальных ценностей. Посягательства на жизнь не могут быть ни восстановлены, ни возмещены. По этой причине, согласно международным и внутригосударственным конституционным нормам, право на жизнь и здоровье являются приоритетными направлениями уголовноправовой защиты. Государственная защита жизни и здоровья начинается с момента рождения человека и продолжается до его смерти [1, с.115].

Первое основное условие проведения исследования в современном уголовном праве является историко-правовой обзор проблемы. Согласно Н.С. Таганцеву, уголовное право является наиболее часто меняющимся среди правовых дисциплин: все политические и социальные изменения очно проявляются в понятиях преступления и наказания, чем быстрее развивается жизнь, тем быстрее проявляются эти изменения [2, с.105].

Историю развития законодательства о насильственных преступлениях против жизни и здоровья женщин в Азербайджане можно разделить на следующие периоды:

1. Период применения мусульманского права в Азербайджане (период ханств - до 1813 г.);

2. Период законодательства Российской империи (1813-1918 гг.);

3. Уголовное законодательство Азербайджанской Народной Республики (1918-1920 гг.);

4. Уголовное законодательство Азербайджана советского периода (1920-1991 гг.);

5. Законодательство независимого Азербайджана в период первых реформ (199101.09.2000 гг.);
6. Действующее уголовное законодательство Азербайджанской Республики (начиная с 01.09.2000 года) [3, с.62-63].

После приобретения независимости в 1991 году, Азербайджан стал участником многочисленных международных организаций, ратифицировал международные акты, принятые в сфере защиты прав и свобод человека. 12 ноября 1995 года путем общенационального референдума была принята Конституция независимой Азербайджанской Республики. Әтим был дан старт формированию новой законодательной базы страны. В этот период, в действующий УК 1960 года, также были внесены важные изменения и дополнения.

Так, 2 апреля 1999 года в Главу 3 УК 1960 года были внесены несколько новых статей. Основным и непосредственным объектом вновь криминализированных деяний были общественные отношения, обеспечивающие безопасность жизни и здоровья женщины: незаконное искусственное оплодотворение и имплантация эмбриона (ст. 115-1); незаконная медицинская стерилизация (ст. 115-2). Жизнь и здоровье женщины могли быть факультативным объектом и иных преступлений, добавленных в УК Законом от 2 апреля 1999 года: изъятие органов или тканей человека для трансплантации без медицинских указаний (ст. 115-3); участие в торговле человеческих органов и тканей (ст. 115-4); незаконное применение новых средств диагностики и лечения, лекарственных средств(ст. 115-6).

В Уголовном кодексе Азербайджанской Республики, принятым 30 декабря 1999 года, вступившим в силу 1 сентября 2000 года, были предусмотрены некоторые новые составы преступления против жизни и здоровья, в том числе сопряженные с насилием против женщин. Новый Уголовный кодекс является более совершенным по сравнению с ранее действующими. $\mathrm{K}$ положительным чертам рассматриваемого кодекса в контексте темы исследования можно отнести объединение соответствующих преступлений, предусмотренных в разных главах в одном разделе - в системе преступлений против личности, классификация преступлений по непосредственному объекту, выбор видов и мер наказания, достаточно совершенная дефиниция этих 
преступлений, точность и последовательность квалифицирующих признаков, конкретизация и закрепление в разных главах половых преступлений и преступлений против нравственности.

На основе анализа преступлений, совершенных против жизни и здоровья женщин в контексте действующего Уголовного кодекса, в зависимости от повлекшихся общественно опасных последствий, последние можно классифицировать следующим образом (следует отметить, что в классификацию были включены не все преступления против жизни и здоровья женщин, а лишь те, которые имеют насильственный характер):

а) преступления, связанные с насильственным лишением жизни женщин: умышленное убийство (ст. 120) и доведение до самоубийства (ст. 125);

б) преступления, связанные с причинением вреда здоровью женщин: (ст. 126-128);

в) преступления против женщин, сопряженные с физическими или психическими страданиями без причинения вреда их здоровью: истязание (ст. 133);

г) преступления, представляющие опасность для жизни и здоровья женщин: угроза убийством или причинением тяжкого вреда здоровью (ст. 134);

д) преступления, связанные с причинением вреда физической свободе женщин: похищение человека, торговля людьми, принудительный труд, незаконное лишение свободы, незаконное помещение в психиатрическую больницу, принуждение женщины к вступлению в брак (ст. 144, 144-1, 144-2, 145, 146, 176 $1)$;

е) преступления против половой неприкосновенности и половой свободы женщин: (ст. 149, 150, 151) [4; 4].

В действующем УК совершение преступления против женщины, заведомо для виновного находящейся в состоянии беременности, считается отягчающим обстоятельством следующих деяний: умышленное убийство (ст. 120.2.8); истязание (ст. 133.2.2); похищение человека (ст. 144.2.2); торговля людьми (ст. 144-1.2.4); принудительный труд(ст. 144-2.2.4); незаконное лишение свободы (ст. 145.2.2); захват заложника (ст. 215.2.6). Кроме того, совершение преступления в от- ношении женщины, заведомо для виновного находящейся в состоянии беременности, может быть оценено судом в качестве отягчающего обстоятельства при индивидуализации наказания (ст. 61.1.7).

Согласно криминологическим исследованиям и судебной практике, насильственные преступления против женщин, как правило, возникают в силу бытовых, внутрисемейных ссор. Бытовое насилие, в том числе внутрисемейное криминальное насилие против женщин? имело место на протяжении веков в разных странах и народах.

В связи с этим, в начале XX века мировое сообщество начало борьбу с деяниями против основных прав и безопасности женщин в контексте нарушения прав человека и дискриминации. В этой сфере были приняты важные международные конвенции. Так, например, начиная с 2000 года, Парламентской Ассамблеей Совета Европы были приняты следующие резолюции и рекомендации, направленные на предупреждение насилия против женщин: Рекомендация о насилии против женщин в Европе (2000); Резолюция о женском обрезании (2001); Рекомендация о бытовом насилии против женщин (2002); Резолюция об убийствах во имя чести (2003); Рекомендация о компании борьбы с насилием против женщин в Европе (2004); Рекомендация о вынужденных и детских браках (2005); Резолюция и Рекомендация об умышленных убийствах женщин и молодых девушек (2009); Резолюция и Рекомендация о деятельности по борьбе с нарушениями прав человека на почве гендерной принадлежности, в том числе с похищениями женщин и молодых девушек (2009); Резолюция и Рекомендация об изнасиловании, в том числе внутрисемейном изнасиловании (2009); Резолюция и Рекомендация о необходимости срочной борьбы с «убийствами чести» (2009); Резолюция и Рекомендация о сексуальном насилии против женщин в период вооруженных конфликтов (2009); Резолюция и Рекомендация о требованиях к убежищам на основе гендерной принадлежности (2010); Резолюция и Рекомендация о детях, ставших свидетелями бытового насилия (2010); Резолюция о психологическом насилии (2011); Резолюция об охранных ордерах для жертв бытового насилия 


\section{Кримінальне право, кримінальний процес та криміналістика}

(2011); Конвенция Совета Европы о предотвращении и борьбе с насилием в отношении женщин и домашним насилием (2011); Резолюция о продвижении Конвенции Совета Европы о предотвращении и борьбе с насилием в отношении женщин и домашним насилием (2012); Резолюция о преследовании с целью сексуального насилия - для предупреждения насилия против женщин (2013); Резолюция о внимании к лицам, совершившим насилие (2014); Резолюция о проституции, торговле людьми и современном рабстве в Европе (2014) [5;11].

Очевидно, что положения о предупреждении насилия против женщин и бытового насилия, закрепленные в многочисленных международных актах, должны определить нормы национального законодательства, направленные на решение этой проблемы.

В начале XXI века в Азербайджане проблема насилия против женщин стала достаточно актуальной. Азербайджанская Республика присоединилась к кампании по борьбе с насилием против женщин, начатой Советом Европы. 21 декабря 2006 года была принята специальная Декларация о борьбе с насилием против женщин, в том числе с бытовым насилием. В Декларации указывалось, что насилие против женщин является бедой мирового масштаба, что она не имеет ни географических, ни возрастных пределов, и ни одна этническая либо религиозная группа не застрахована от этой беды.

Юридическая дефиниция бытового насилия дана в Законе Азербайджанской Республики «О предотвращении бытового насилия» от 22 июня 2010 года следующим образом: «Бытовое насилие - умышленное причинение физического либо морального вреда друг другу лицами, на которых распространяется настоящий Закон, путем злоупотребления близкими родственными отношениями, нынешним либо прежним совместным проживанием» $[6 ; 15]$.

На основании вышеизложенного можно придти к нижеследующим выводам.

Совершенствование действующего уголовного законодательства Азербайджанской Республики должно основываться не только на прогнозировании сегодняшнего, завтрашнего и будущего состояния преступности, оно должно принять во внимание и историю развития уголовного закона, его преемственность.

Как во всех трех Уголовных кодексах советского периода (1922, 1927, 1960 гг.), так и в действующем уголовном законе Азербайджанской Республики от 1999 года, система преступлений против жизни и здоровья была закреплена в одной главе. Учитывая исторические, социальные, криминологические условия и нравственные ценности каждого исторического периода, можно сделать вывод, что в каждом из них основные неотъемлемые права (права на жизнь, на здоровье, половую неприкосновенность, половую свободу, достоинство) женщины охранялись в должной степени.

Вместе с тем, считаем, что в ближайшем будущем в действующем уголовном законодательстве должны быть решены следующие вопросы.

К сожалению, преступления на почве внутрисемейного насилия совершаются во всем мире, они возникают вне зависимости от материального и социального положения семьи, и в характерной форме для разных уровней цивилизованности [7, с.4-10]. Согласно утверждениям аналитиков, 40 \% насильственных преступлений совершаются в семьях.А жертвами таких преступлений, в основном, становятся женщины. Например, согласно официальным статистическим данным 2019 года по Азербайджану, 85 \% жертв умышленных убийств (ст. 120 УК) на почве бытового насилия составили женщины [8]. Кроме того, в случаях, когда в деяниях по умышленному убийству не устанавливаются отягчающие обстоятельства, предусмотренные в ст. 120.2 УК, убийство женщины (матери, сестры, жены, обрученной, иной женщины-родственницы) на почве бытового насилия квалифицируется как «простое убийство на почве ревности» по ст. 120.1 УК. В таких случаях насилие на почве семейно-бытовых отношений не только остается без соответствующей юридической оценки, но и намерение изощренного гегемонства маскируется под мотивом «ревности».

Учитывая международные акты, принятые в этой сфере за последнее годы, а также Закон Азербайджанской Республики «О предотвращении бытового насилия» от 2010 
года, считаем, что для разрешения проблемы насилия против женщин в рамках действующего уголовного законодательства настало время криминализации деяний на почве внутрисемейного бытового насилия (например, путем дополнения Главы 18 УК АР новым видом преступления - бытовое насилие), либо дополнения действующих норм новыми отягчающими обстоятельствами (например, умышленное убийство женщины (ст. 120.2), доведения до самоубийства женщины(ст. 125.2), причинение вреда здоровью, угроза убийством, либо причинением вреда здоровью женщины (ст.ст. 126.2, 127.2, 128.2, 133.2, 134.2), истязание женщины (133.2), изнасилование женщины (149.2), насильственные действия сексуального характера в отношении женщины (150.2) на почве внутрисемейных отношений).

Следует также учесть, что в некоторых странах Европы и в постсоветских странах преступления бытового насилия предусмотрены в отдельных главах уголовного законодательства, в связи с чем считаем, что в Азербайджанском уголовном законодательстве тоже должна быть сформирована полная система преступлений бытового насилия (например, в форме отягчающих составов преступлений против личности). Кроме того, совершение насильственного преступления на почве семейно-бытовых отношений должно выступить в качестве критерия дифференциации уголовной ответственности в нормах Особенной части УК АР, так и в качестве критерия индивидуализации наказания в перечне отягчающих наказание обстоятельств в Общей части УК АР (ст. 61).

\section{\итература}

1. Самедова II.Т. Уголовное право Азербайджанской Республики. Особенная часть: в двух томах. Учебник. Баку: Адильоглы, 2020, т.1, 824 c.

2. Таганцев Н.С.Русское уголовное право. Лекции. Часть общая:в двух томах / Сост. и отв. ред. Загородников Н.И. М.: Наука,том 1, 380 с.

3. Самедова II.Т. Категории преступлений. Баку: Адилоглу, 2007, 314 с.

4. Уголовный кодекс Азербайджанской Республики. Баку: Юридическая литература, 2000, 350 c.
5. Стамбульская конвенция Совета Европы О предупреждении насилия в отношении женщин, бытового насилия и борьбе с ним / Настольная книга для членов парламента. Баку, 2016, 108 c.

6. Собрание законодательства Азербайджанской Республики о предупреждении Бытового насилия в семье. Баку, 2012, 80 с.

7. Домашнее насилие по законодательству зарубежных стран: ответственность и превенция / Отв. ред. Н.А. Голованова. М.: Юстицуинформ, 2011, 384 c.

8. Преступность и правонарушения в Азербайджане / Статистический сборник. Официальное издание. Баку, 2020, 110 стр. URL: www.stat.gov.az/source/crimes/

\section{VIOLENT GRIMES AGAINST WOMEN: A HISTORICAL OVERVIEW}

Criminal acts caused by domestic violence occur all over the world, while neither the different levels of the culture of the people and the welfare of the state, far less the material and social situation of the family, play a significant role. Thus, about $40 \%$ of violent crimes occur in families. And in this case, the victims of most of these crimes are women. In the criminal legislation of many European countries and some states that have emerged in the post-Soviet space, crimes related to domestic violence are even singled out as independent chapters, and domestic violence is criminalized as an independent type of crime.

The article indicates that, taking into account the historical, social, criminological conditions and moral values, in every historical period in the criminal law of Azerbaijan, the basic inalienable rights of women (life, health, sexual integrity, personal freedom and dignity) were sufficiently protected. According to the author, the system of crimes of domestic violence should also be fully formed in the current criminal legislation of the Republic of Azerbaijan. Violent crimes committed in general on the basis of family and domestic relations should be defined as criteria for differentiating criminal liability for relevant crimes both in the Special Part of the Criminal Code (as aggravating elements of the corresponding types of violent crimes against the individual) and in the list of aggravating circumstances, punishment in the General Part of the Criminal Code (Article 61 ) as criteria for the individualization of punishment.

Key words: criminal law, crime, punishment, criminal responsibility, violent crimes, crimes against life and health, violent crimes against women. 